\title{
Pesquisas de desenvolvimento da Telebrás
}

Gil Floro Popoire Azevedo, chefe do Departamento de Apoio Técnico do Centro de

Pesquisa e Desenvolvimento da Telecomunicações Brasileiras - Telebrás.

\section{Gil Floro Popoire Azevedo}

O Centro de Pesquisas de Desenvolvimento da Telebrás, em Campinas, desenvolve produtos desde sistemas de comunicação por satélites até a microeletrônica, compreendendo dispositivos e circuitos integrados como insumos para as nossas atividades, passando por sistemas de transmissão digital, comunicação de dados, centrais telefônicas controladas por computador, sistema de comunicação ótica utilizando laser e fibras óticas, enfim, trabalha com tecnologia de ponta na área de eletrônica.

Cabe aqui ressaltar alguns pontos: tudo o que fazemos contamos com parceiros muito importantes; atuamos com algumas universidades e centros de pesquisa e indústrias, na medida em que, entre os nossos objetivos, é exatamente criar, gerar essa tecnologia e transferir para as indústrias, de modo que elas possam ocupar um papel de suprimento, enfim, de fornecimento das nossas necessidades. Tudo isso é feito também com recursos próprios, gerados pela receita bruta operacional do Sistema Telebrás, composto de várias empresas concessionárias de serviços de telecomunicações e tráfego internacional, também, de telecomunicações e do nosso orçamento de custeio operacional que representa cerca de $1,3 \%$ a $1,5 \%$ dessa renda bruta isso hoje monta à ordem de 5 bilhões de cruzeiros, dos quais aplicamos $40 \%$ nessas atividades complementares, nas indústrias e universidades. Há ainda necessidade muito grande de investimentos específicos, em termos de instalações especiais, laboratórios, equipamentos e máquinas para processos, sem o que é praticamente impossível competir na manipulação de tecnologia e atingir um patamar, compatível com essas necessidades. Inclusive, acompanhando a própria Embraer, também adquirimos um computer design sistema complexo, da mesma forma como a Metal Leve dispõe desses recursos, e essas facilidades, hoje em dia, são vitais dentro desse contexto de tecnologia.

Temos também parceiros importantíssimos: a Finep, o próprio INPI, que muito pacientemente nos tem auxiliado na formulação de patentes, na defesa de posições, enfim detemos hoje cerca de 170 patentes num espaço de três anos.
Por razões de natureza estratégica, no âmbito de um convênio de cooperação técnica a nível internacional, descortinamos a oportunidade de queimar algumas etapas, tanto em tempo quanto em custo, no curso do desenvolvimento de alguns produtos, adquirindo a tecnologia de determinado insumo. $\mathrm{Na}$ realidade não se tratava de comprar uma receita de bolo, sabíamos exatamente o que queríamos, senão pelo fato de já estarmos desenvolvendo algumas etapas desse processo de obtenção daquele insumo há algum tempo. Aí começaram as nossas dificuldades. Tal reivindicação soava pelo menos como uma heresia no processo vigente de transferência de tecnologia. A outra parte tentou convencer as autoridades do nosso setor de que nós precisávamos, isto sim, de um pacote de 30 milhões de dólares. Só que tal pacote era corroído por uma inflação de vários dígitos, magro no conteúdo. Aliás, não correspondia ao nosso interesse, o que pôde ser facilmente detectado na primeira visita que realizamos ao detentor da tecnologia. As negociações duraram mais de dois anos, com um enorme desgaste a nível de relação internacional, pelas implicações ancilares de todo esse processo, interesses em outros campos a nível de mercado nacional.

É bom abrir um parêntese: a nosso entender a tecnologia é uma mercadoria e, como tal, regida pelas leis de mercado. No mínimo estávamos nos tornando um competidor em potencial bastante incômodo para vir ocupar um segmento com enormes perspectivas para atuação futura de uma subsidiária daquela matriz. Ainda bem que existem os advogados, porque suprimos nossas deficiências, as deficiências de nossa equipe técnica, nas negociações, com assessoria jurídica de nossa empresa.

Quanto a outra parte, o que causou bastante espécie, foi o fato de que não tinham um só advogado; eles tinham vários advogados e, vamos dizer, até advogados tecnólogos, com conhecimentos profundos inclusive em etapa de processos e com conhecimentos sólidos da legislação brasileira. Nós tivemos que colocar a carapuça nos engenheiros, na hora de negociar nesse nível, a insipiência, talvez seja até uma deficiência de formação nossa. Tudo isso 
aliado a um forte e determinado respaldo político de outros escalões do governo. Felizmente, essa seqüência interminável de negociações teve, fundamentalmente, um apoio coerente do governo. Finalmente conseguimos fechar um contrato de transferência de tecnologia no valor de 3 milhões de dólares, cobrindo exatamente o que pretendíamos e com algumas vantagens. Por exemplo, não havia restrições para repassarmos os conhecimentos a uma empresa fabricante genuinamente nacional. Essa era uma exigência que não abríamos mão, porque, em última análise, a nossa atividade não seria de fabricar, nós estávamos apenas interessados em trazer esse processo porque esse insumo era importante no desenvolvimento e na realização de alguns produtos e a conseqüência natural, tendo em vista o mercado interno de utilização desses insumos, seria passar isso para um fabricante nacional.

Outra coisa que conseguimos, foi o treinamento e a capacitação do nosso pessoal no exterior, em todas as etapas do desenvolvimento do processo de obtenção desse insumo inclusive com o acesso ao know-why que era o que nos interessava. Nós queríamos mudar algumas coisas em função de outros desdobramentos, de outras aplicações e obtivemos também a assistência técnica do fornecedor na instalação e operacionalização de nossa planta-piloto. Inclusive, na medida em que estivéssemos com essa planta em fase de instalação queríamos realizar algumas corridas, digamos assim, de produção desses insumos, nas facilidades existentes na empresa cedente da tecnologia no exterior, queríamos garantias desse aspecto sem custos adicionais.

Outra coisa importante, também conseguida, foi o cronograma de pagamento, escalonado em função do cumprimento sucessivo das diversas etapas do processo. Enfim, tínhamos que escutar os pontos de verificação, que também exigimos; então cada pagamento ficava condicionado a nossa aceitação técnica.

Finalmente, na questão pertinente: nessa linha de atuação como país emergente, determinado e consciente de suas necessidades, não estaremos violando alguma regra intangível do clube dos detentores de tecnologia? Outras experiências serão bem-sucedidas ou terá sido um puro golpe de sorte da nossa parte? Na medida em que adquirirmos competência, as portas não estarão se fechando para determinadas pretensões nossas?

\section{Tecnologia como participação de capital}

Samia Rashed, doutora em direito internacional privado (Universidade do Cairo) e consultoralegal em direito internacional.
Samia Rashed

Ihes-ão que precisam de fazer um contrato de transferência de patente, visto que aquela não é reconhecida como participação em espécie. Noutros países, contudo, entre eles o Egito, a tecnologia é aceita e até bem-vinda como participação em espécie, em qualquer companhia. Aceitamo-la, porque nesse caso não precisamos de pagar royalty, não precisamos de despender dinheiro: pelo contrário, obtemo-lo facilmente e com isso promovemos a economia do nosso país. O grande problema está em como avaliar essa tecnologia. Em países como o Egito, por exemplo, a tecnologia é patenteada e como tal pode ser aceita na economia como uma participação em espécie.

Recusamos a participação em espécie de tecnologia que não esteja patenteada, porque achamos 